\title{
The Song of Nature, The Song of Hope: J. H. Prynne's Pearls that Were
}

\begin{abstract}
The present article investigates J. H. Prynne's 1999 volume Pearl that Were for the tensions between man's fallibility and the song of nature, which is revealed as poetry's proper domain. Prynne's imagery is traced to various Renaissance, Romantic and contemporary poetic instantiations of the themes of nature and the body as inscribed in language. As a result, the dense allusive texture of Pearls that Were is shown to be underlain with a conflict between the dominance-obsessed but ailing man and an ever more silent voice of poetry, which is here demonstrated to be a composite trope of marginalised figures: from fauna and flora, to the impoverished, all the way to women. Finally, against the destitute background, I argue that the volume offers hope that runs counter to maladies the volume thematises.
\end{abstract}

\section{Keywords}

J. H. Prynne; poetic voice; Romanticism; contemporary poetry

Granted that J. H. Prynne's formal difficulty, variously celebrated and deplored across the English-language criticism, has opposed the dominant mode of discourse whereby communication is paramount, his artistic project departs from an Adornian premise that "the greatness of works of art lies solely in their power to let those things be heard which ideology conceals" (Adorno 2006: 214). Partly, it is the dialectic nature of Prynne's work coupled with indomitable experimentalism that stand behind the neo-modernist tag that is often attached to his poetry (Mengham and Kinsella included Prynne in their anthology Vanishing Points: New Modernist Poems; see also Mellors 2005: 117-143). Yet being one of the most protean contemporary poets, Prynne eludes labels as easily as he reconfigures 
the English syntax. Nevertheless, identifying the predecessors of his work serves the exegetic purpose much better than imposing hefty short-hands, for Prynne seems primarily to conceive of poetic language, but also language in general, as informed by prior uses. For Prynne, literature is to some degree the domain of the arbitrary sign, as he observes following de Sausurre: "the sign is arbitrary" and "designates the correlation of the idea with the image of its acoustic performance, taken together as a unit; both parts of this bipartite entity are mentalistic, existing within a system of differences by which separate ideas are distinguished" (Prynne 1993: 5). Thus a work of literature becomes what Roland Barthes defines as the text whose ambiguity depends "on what might be called the stereographic plurality of its weave of signifiers (etymologically, the text is a tissue, a woven fabric)" (Barthes 1977: 159). Graham Allen pithily summarises the perception of text that Barthes but also Derrida (in the early period of Grammatology and Writing and Difference) and Bakhtin have brought to the fore: "the theory of the text [...] involves a theory of intertextuality, since the text not only sets going a plurality of meanings but is also woven out of numerous discourses and spun from already existent meaning" (Allen 2000: 67). However, Prynne is more sceptical of arbitrariness than may appear from a cursory glance over his theoretical and artistic work. In the lecture Starts, Tigers and the Shape of Words, he argues that "if language is a social code of interactions, [...] then anything that can count towards meaning may do so: intonation, style-level, choice of words and of their sounds and echoes" (Prynne 1993: 1). Arbitrariness is checked and, as Prynne says, "has to be overwritten and re-mapped by a corpus of optional and variable connections secondarily imposed, so that literary motivation is essentially retrospective." As a result, "almost $[\ldots]$ the more complex become the inter-connections of this associative and relational network of features, the less arbitrary becomes the whole of its ensemble and thus each of its components" (Prynne 1993: 14). In light of this claim, the importance of investigating poetic antecedents for a particular poem or sequence of poems becomes a crucial interpretive starting point.

Much of Prynne's poetry, especially the earlier work in Kitchen Poems and The White Stones, utilises the experimental work of American poets of the post-WWII era, with particular prominence given to Charles Olson and Edward Dorn, while in terms of his implementation of discourses of economy and medieval philosophy coupled with an unflagging interest in classical Chinese poetry point out to Pound. This modernist ensemble fits the general perception of Prynne's work but grossly limits the scope of its critical reception. Prynne is unorthodox in his quest for linguistic novelty, canvassing the history of English language poetry from Piers Plowman (which underpins his last long poem Kazoo Dreamboats) to metaphysical poets, to the Romantics and beyond. The key is whether the poems that he alludes to can help him invoke the contemporary world and its discontents. Among those discontents Prynne's commentators mention the surrender to the reign of specialised discourses, especially of economy, science and medicine (Reeve and Kerridge 7-9, Mengham 2009: 72-73), which is for Prynne the modern-day representation of false consciousness. Apart from those jargons, Prynne is acutely aware of the 
threats inherent in man's reckless treatment of earth's natural resources as well as his oblivion, on a metaphysical and ontological level, to the fact that there is a growing gap between him and nature. People tend to abstract themselves from their environment as they place their trust in what seem to be modern-world enchantments: "Suffusive dram opening on automatic, spruce / on Velcro your family trip / to a far-fetched accumulation: hail / goitre retrieval, [...] fast-food morsel resale" (Prynne 2004: 485). This fragment from Triodes, Book I (1999) returns to the artificiality of the world of surrogate experiences that already ached Wordsworth, who agonised in "Tintern Abbey": "In darkness and amid the many shapes / Of joyless daylight; when the fretful stir / unprofitable, and the fever of the world, / Have hung upon the beatings of my heart" (121, 11. 52-55).

In his book-length commentary on Wordsworth's "The Solitary Reaper," Prynne observes that the georgic scheme drew for Wordsworth "its sanction from a theological providence or an Enlightenment idea of cultivation in its many senses, or more diffusely from a political sentiment of coherent land ownership and property rights, functionally mapped onto class and pedigree, which is assumed as likewise stable and likewise benign" (2007: 5). In order to keep up this idea of "cultivation," Wordsworth, as Annabel Patterson (approvingly cited by Prynne) says, turned to "a hard pastoral whose entire logic is georgic. The solution to the ethical dilemma posed by rural labor, as Wordsworth now saw it, was both to endorse its necessity and to insist on its dignity, and in the occupation of the shepherd as it actually survived in the Lake District he was able to reconcile his own poetic program with a philosophical view of work that transcended and obscured the social issues" (qtd. in Prynne 2007: 25). In his reading of "The Solitary Reaper," Prynne unravels those moments of ideological suppression of the realisation that the poet celebrates an image of the reaper that he constructs for his own ends, while silencing such issues as remuneration, or lack thereof, for the labour in the field and the labour over the poem or the silencing of the native language in which the reaper sings, though we never learn what song (Prynne 2007: 29). Despite the differences in social, financial and educational stature between the poet and the reaper, Prynne identifies a moment of reciprocation: "Just for the moment of the encounter, [the reaper's] realised performance and [the poet's] potential counterpart composition depend reciprocally upon each other, hers in his poet-memory, and his upon a future page" (2007: 29). Therefore the reaper becomes a proxy for the poet, who has no access to the natural rhythms of the land that remain as silent to him as the reaper's words are to us. It is this severance from the natural world that underlies one of Prynne's most eloquent sequences, Pearls that Were (1999). In what follows, I investigate the volume for the tensions between man's fragility as well as fallibility and the song of nature, which in the process is revealed as poetry's proper domain.

The title of the volume opens a string of allusions that go back to Shakespeare's The Tempest. In Act I, Scene ii, Ariel sings to Ferdinand the well-known song: 'Full fathom five thy father lies; / Of his bones are coral made; / Those are pearls that were his eyes" (Shakespeare 56). This context is important for setting the motifs of 
Prynne's volume, for Ariel approaches Ferdinand at Prospero's bidding and after being reprimanded by the magician for his tarry attitude: "If thou more murmur'st, I will rend an oak / And peg thee in his knotty entrails till / Thou has howled away twelve winters" (Shakespeare 52). Prospero alludes to the torment that Ariel had to endure at the hands of the witch Sycorax, who imprisoned the spirit in a tree for a dozen years. Yet, "Prospero's relationship with Ariel [...] demonstrates the deceptive nature of Prospero's modus operandi" in that he "uses the illusory promise of freedom to manipulate Ariel into performing complicated tasks, a practice he continues until the very last lines of the play" (Breuer 104). Prospero's “duplicitous manipulation of the spirit's sense of gratitude" (Breuer 105) makes him no better than Sycorax and a precursor figure of the coloniser, as Aimé Césaire in his Une Tempête and Kamau Brathwaite in Letter Sycorax have shown him to be. Prynne's poem returns to a critical reading of The Tempest in the mode of Césaire and Brathwaite but for him, it is not the postcolonial context that matters but Prospero's abuse of Ariel as a spirit of nature (Kevin Nolan's point that Pearls takes up, via Hawthorne's The Scarlet Letter, the theme of "Puritan control ethics" is also apposite [Nolan] in that the undergirding criticism of radicalism, including religious dogmatism, is part of the critical stance in Prynne's volume). The critical approach to attempts at subjugating nature to man's will are given ample commentary in Prynne's study of Shakespeare's Sonnet 94, "They that Haue Powre to Hurt." In regard to the use of the "stone" simile in line 3 of the sonnet, Prynne argues that "a deep underlying theme of the sonnet and indeed of the sequence is that the dispute over loyalty, change, transience within time and the pathos of beauty's moment, either this way or that, is all by necessity vain: only stone is durable, endures, neither sweet nor sour, chaste nor corrupt" (2001: 31). Whatever man's outward goals over nature are, its stony presence cannot be willed away. Following in the same vein as the commentary on Shakespeare, Pearls that Were is closer to Eliot's denunciation of magic and clairvoyance (both being pre-modern arts appropriated by the modern culture but with none of their primitive potency) in the figure of Madame Sosostris, who parenthetically quotes "(Those are pearls that were his eyes. Look!)" (Eliot 54, 11. 43-50) than Auden's hesitant "One evaporating sigh" that Ariel says that he and Caliban "shall become" (Auden 445).

In the first half of Pearls that Were, images of landscapes abound. The fourth poem in the sequence opens with an evocation of connectedness within the natural world:

To swell up so long, this time indwelling in clouds going to flowers,

in order routine adjunct and smother the meaner grace, below us. (Prynne 2004: 458)

While the "clouds going to flowers" calls up the already evoked "Tintern Abbey": "Once again / Do I [...] connect / The landscape with the quiet of the sky" (Wordsworth 120, 11. 4-5, 7), "the meaner grace, below us" sharply departs from 
Wordsworth's optimism in his perception of his sister whose "memory be as a dwelling-place / For all sweet sounds and harmonies" (Wordsworth 124, 11. 142143). Whereas Wordsworth seeks to uncover a dwelling place of the memory of the past unity with nature, “when like a roe / I bounded o'er the mountains, by the sides / Of the deep rivers, and the lonely streams" (Wordsworth 122, 11. 68-70), Prynne sees artificiality in that attempt to establish an "indwelling" between man and nature; this is in tune with Prynne's criticism of the georgic scheme employed by Wordsworth who, in Prynne's view, uses the reaper, like he does his sister in "Tintern Abbey" and by extension the georgic scheme, to help his imagination flourish. If there is anything to be gained from such apprehension of nature, it is "order routine adjunct and smother / the meaner grace." As the sequence proceeds, the recurrent images of nature summon implications of the destruction of the environment:

Too single! caress fronds as to liberate race hatred's package tour

whose every touch, kiss the rising hand will too bleach-whiten yours. (Prynne 2004: 458)

Even though the first line implies intimacy with trees, perhaps attempts to come to their succour as they are "Too single!" too often left all alone, the following lines bring in the rampaging "package tour" that comes to "bleach-whiten yours;" the possessive pronoun appears to denote "the rising hand," hence the implication of a colonial context: the rising hand will be bleached white by the "race hatred's" tourist.

This violent attitude to the environment (and its native inhabitants, whether human, spirit or animal), emphasising a disconnection between man and nature, becomes the focus of the ballad-like "[Shine ahead]," the fifth poem in Pearls that Were. The first stanza juxtaposes a lyrical image of harmony: "Shine ahead cold star / like music on the water," with a deadly disease: "in the wake of remission" (Prynne 2004: 459). The opening belongs with the treasures of the language's starry lyrics: Blake's "To the Evening Star" ("Let thy west wing sleep on / The lake" [Blake 392, 11. 8-9]) and Keats's "[Bright Star]" ("would I were stedfast as thou art / [...] / And watching, with eternal lids apart, [...]/ The moving waters at their priestlike task" [Keats 372, 11. 1-5]); against this background, the suggestion of "remission" clearly dwarfs man, the sickly fragile being that can only look at the grandeur of the universe that is in no way connected to him. One is reminded of a similar feeling of human insignificance in Louis MacNeice's famous "Stargazer,' in which the speaker, admiring "a brilliant starry night," realises that he is "adding noughts in vain" to the boundless universe (MacNeice 544). Yet Prynne goes on to invoke other sharp divisions: "beauty's injunction / [...]/ that binds up the open scatter" is set against "chill rain;" "client deception" and "vocal induration" become "motionless, undistracted / insult to charm" (Prynne 2004: 459). Among the connotations of the subsequent stanzas of the poem one may place 
celebrity culture and advertising (both often criticised by Prynne, especially in his earlier News of Warring Clans and the recent Kazoo Dreamboats or, On What There Is). It is the latter that seems particularly offensive in that advertising slogans, as the poem suggests, play on clichéd uses of pun and melodic consonance to create poetry reified to suit standard popular tastes. This precipitates the collapse of poetry as a charm, an enchantment whose efficacy pivots on the particular orchestration, as the magician-poet, W. B. Yeats, asserted in his early essay "Magic" (Yeats 28-39). Once an elite poet's boon thanks to which he (admittedly, less frequently she) could control nature: "So Orpheus tamed the wild beasts" (Prynne 2004: 455), "the charm" eventually ends up "diving like a crashed star / in salt water, outbroken fire" (Prynne 2004: 460), it vanishes as "the leaves go down, all in yellow / faring well, to pass by" (Prynne 2004: 464). Therefore people's separation from nature is not only due to the increasing artificiality of their life and heedless treatment of the environment, but also to the fact that poetry as charm no longer allows one to regain, even if only for a brief moment, the past harmony, like it did for Wordsworth.

For Prynne, the condition of modern man is one of permanent deracination both from his natural environment and his language conceived of as a link between life processes and social existence. This painful situation is further exacerbated by the deepening crisis of linguistic creativity, with people preferring lower standards to difficult experimentation:

Newly arise the classics in paraphrase, newly precentral in a livid bond

to touch daylight and brush its wing fluently, with all found. (Prynne 2004: 466)

The quotation from Pound's Hugh Selwyn Mauberley in the first line of the poem ushers in a critical aspect of Pearls that Were. The artificiality that has so far been presented as a way of compensating for man's fragility now signals the debilitating effect that the uprootedness exerts on the entire society. In Mauberley, the character E.P. laments the collapse of culture:

The age demanded an image

Of its accelerated grimace,

Something for the modern stage,

Not, at any rate, an Attic grace;

Not, not certainly, the obscure reveries

Of the inward gaze;

Better mendacities

Than the classics in paraphrase! (Pound 10)

Just as Mauberley records the disappearance of "the "better tradition"” (Pound 
26) following the loss of numerous men of genius in WWI, so Pearl that Were demonstrates the growing oblivion into which modern man descends. Now "the rush begins its fervent ransom" as people succumb to the false consciousness of "cryptic subliminal choke" and "open / audition right to the quick" (Prynne 2004: 466). Everything must be named, gauged and given "a brother token / or the tag for his naming" (Prynne 2004: 466).

As a result, people and the world that Prynne images forth in Pearl that Were are ailing intellectually ("the classics in paraphrase") as well as both mentally and physically; except the implication of "remission," man is "hiked up ahead / for degraded lesions," as "hic clinic // yearning to clank, to bind over, to fawn / its botched curtailment - spectrum on blank" (Prynne 2004: 468). The mental, intellectual and physical debilitation fuse in the recurring images of failing eyesight, of being "dazzled in their eyes" (Prynne 2004: 456), that the sequence consistently deploys in order to emphasise man's inability to comprehend his condition, his being "demented stuck in // wonder or / peep like bats and black / owl on wires" (Prynne 2004: 467). The idea that senses do not offer a lens through which one can approach the material world has long been present in Prynne, dating back to Kitchen Poems, though it is given a particularly revealing and pertinent treatment in Oval Window:

Changes to the real data

are visible through the view; and operations

against the view are converted, through

a kind of unofficial window on Treasury policy,

into operations on the real data. (2004: 319)

The manipulation of sight triggers no wariness that the sense distorts the view; instead, the resultant image of "the real data" is accepted as true. However, in Pearls that Were, the consequences of skewering the sense of sight are more dire, for this bodily decrepitude is linked with the failure of the reproductive system:

The seed searches itself, its sac defunctive

by crow flight pinioned to bind

an open heart upon a table, rigged

ethereal, towards its end. (Prynne 2004: 469)

The direct medical observation that the sac is defunctive (one poem earlier, we learn that "your bragged synovial / glimmer threshold raves and stamps in garniture" [Prynne, Poems 468]) is immediately transposed on the mythical level. Evocations of "crow" recur throughout Pearls that Were, which would have brought a distinct mourning note to the sequence when it was published in 1999, less than a year after Ted Hughes's demise of cancer, "in the wake of remission." But the position of Hughes in Prynne's volume is more important than the incidental concurrence of dates, for Hughes is a valid point of reference for Prynne, even if this reference 
has generally been viewed as contrast (Reeve an Kerridge 31-32; Easthope 21).

While Hughes, especially valid for Prynne is the Crow period, famously seeks "a super-simple and super-ugly language which would [...] shed everything except just what [Crow] wanted to say" (Faas 1980: 208), Prynne, as has been suggested above, desires a complexity of inter-connectedness of images and syntax. However, Hughes's Crow, as an embodiment of the Trickster figure, is conceived as the "demon of phallic energy, bearing the spirit of the sperm, [it] is repetitive and indestructible" (Hughes, Winter Pollen 241). It is the qualities like endurance, virility and liveliness, that are pronouncedly lacking in the people of Pearls that Were. While the whole world of nature is shown to be orderly and productive, men are hectic and ineffective:

Freely bees awaken, rising to many tasks in jaunty flights forsaken, turning enrolled to occupy their sentimental places and polish off their finer tuning.

Trace the residuals, the throng of men who surmount the dative assignments

as if inching wildly, crazed for upper lights that flood what they want. (Prynne 2004: 470)

There might be a tinge of cruelty about this poem, as bees, another element of the georgic featuring "in jaunty flights forsaken" beside the crows, would invoke, after the release of Hughes's Birthday Letters in 1998 all the more so, Sylvia Plath's bee sequence (though Prynne employed some references to bees, notably in "Again in the Back Cloud"). Also, the figure of Ariel implied in the Shakespearean undertone of the volume's title would serve to further emphasise Plath's presence in the sequence. Nevertheless, although Prynne's bees are in no way the ferocious force subservient to the will of the queen, "With her lion-red body, her wings of glass" (Plath 1965: 62), they do make the male "residuals" seem inferior to the feminine orchestration.

This tension between nature as the productive female and the stultified, ailing man percolates across the entire volume but never trails off into mere conflict with the roles of the oppressed and the oppressor permanently assigned. Instead, Pearls that Were seems to be underlain with a hope that the severance, which adversely affects both man and nature, can be patched up. The sequence features throughout evocation of a female figure. She may be a symbol of autotelic poetry: "all voice / and nothing fit to eat" (Prynne 2004: 469); she is irreducible to nature: "her sight / not measured in the leaves of trembling ash" (Prynne 2004: 470); but is also a practical woman: "she'll advise / to mend both shirts, and steal / a heart-felt fury, burning up charcoal / in guise for kitchen foil" (Prynne 2004: 471). However, most crucially, as it seems, she is a lady to be wooed: 
Up in sparkling glee, over wide salt sea oh madam don't be coy

for all your glory, fear of another day and another story. (Prynne 2004: 465)

The stanza borrows an anonymous folk song, "The Pain of Love," which Benjamin Britten set to music in 1961. In the folk song, the lady declines the advances of an honest young farmer, claiming "I am for a lively lad with lands and riches;" eventually, however, she falls for "A sooty collier" and the young farmer is left with a bitter conclusion: "The widow's mazed, I'm sure. / I'll never go no more / Courting a widow" (Anonymous 65). One may also detect a note of Andrew Marvell's "To His Coy Mistress," in which the urbane speaker calls to his beloved: "Had we but world enough, and time, / This coyness, lady, were no crime" (Marvell 23). In Prynne, the lady's resistance to amours represents another layer of tension, this time between man and woman. Even though she is as loath to accept the courtship as the women in the two just mentioned poems, Prynne comes to strike an incongruously optimistic note towards the end of Pearls that Were.

In the penultimate poem in the sequence, birds return, as "Chirrup in the morning up on sky / lines ahead" (Prynne 2004: 473). This is no Crow anti-music but an invocation of merry-making birds that seem to be sharing in a carnivalesque celebration:

Did the swale open, lose design token borders, the bursting ribbon fluent with margin overflow licks up salt on its own. (Prynne 2004: 473)

The rules that dictate the social and economic organisation of the world are undermined: the "design" is lost or, as an earlier poem puts it, becomes a "levity of design" (Prynne 2004: 462), the "margin" overflows and admits nature, though not without cost. The "ribbon" may be "fluent with margin overflow" but it is still left all alone to fend for itself; poetry, the female voice attended to throughout the sequence, is not "fit to eat," if anything, one may only "lick up salt." As a result, the joyous "chirrup" is in no way justified, as the last stanza sardonically reminds us:

In trivial deep amazement, murmur its song in outward seeming return from a glow foiled to release its wanton, loving primer. (Prynne 2004: 473)

Although there is no subject in the sentence that comprises the stanza, "murmur" and "its song" suggest a bird, the voice of nature absent but heard. Thus the stanza summons Shelley's "Skylark" (though not Keats's "Nightingale"), which is "unseen, but yet I hear thy shrill delight" (764) The skylark is for Shelley "Like 
a Poet hidden / In the light of thought, / Singing hymns unbidden" (Shelley 764) and its song, in accordance with his postulate from A Defence of Poetry, takes dominion over popular imagination "Till the world is wrought / To sympathy with hopes and fears it heeded not" (Shelley 765). For Prynne, this mode-defining role of poetry is implausible. His bird-as-voice may "murmur / its song in outward seeming" but this is only a "trivial amazement" of a "wanton, loving primer."

If the "levity of design" and the loosened order of the alienated world are to oppose the mounting reification of man in his world, if the female voice is to be seen, not only heard, the effort to undermine the design in all its forms and aspects must become an incessant and negative practice. This negativity needs to be understood after Adorno as "consistent consciousness of non-identity" (1973: 5) in that each linguistic representation of the world that a poem should offer must always hinge on the premise that its validity, its correspondence to the object it denotes, needs to be questioned from the very moment it is proffered by the poet. Thus the bird in the penultimate poem of Pearls that Were can only manifest itself as presence-in-song insofar as this song breaks up its "murmur" so that, unlike Shelley's skylark, the singer can only succeed if he or she starts each time from scratch. In Prynne's case, the radical paratactic swerves and jarring syntax may be regarded as attempts at just such starting anew.

The last poem in Pearls that Were returns to the seduction metaphor, the context implied by one of the earlier poem's implementation of Marvell and the folk song:

Much like waves upon a shore whose day approaches,

her time running to meet

with joy the face it touches,

And word upon word, step

by next step regaining

they'll walk and talk, wisely

flicker some hope remaining. (Prynne 2004: 474)

The landscape, so much of which has already been proffered throughout the sequence, is well-ensconced in the English poetic tradition but here the evocation of the sea is coupled with a distinct implication of sadness, for the day of those waves approaches, as it does for "her" who is "running to meet / with joy the face it touches." Still, the impression that little time is given to her and that joyful "face" she is as joyfully running to meet serves only to increase the intensity of the last stanza. Although the "they" is unclear, for no man has been invoked as consistently as the woman, it seems that it could be the couple that was already introduced in the pastiche-stanza of the folk song. Thus the woman, the bird-like voice, the landscape, the native poetic element, meets with the man, the ailing sufferer bent on "accumulators" and "rhodopsin." Despite the fact that they do not have "world enough, and time," they are shown to "walk and talk, wisely." 
There is ample evidence in the poem to assume that the relationship cannot last but this does not preclude hope.

The final moment of hopefulness, which seems characteristic for Prynne, does not represent a happy end in the sense that the resolution in The Tempest brings to all. Prynne is well-aware that Prospero's dismissal of his powers and liberation of Ariel, though not without a last request, must ring false for a modern poet. Walking and talking, "renewing and walking" (Prynne 2004: 474), have no end if the threatening design is to be kept a little looser. By the end of the volume, the body has not been healed of its maladies, the crisis of culture has not been alleviated and the sight continues to tremble but the poetic voice, like the indomitably tricky crow but more self-aware, manages to endure.

\section{Acknowledgements}

When completing the paper the author has been supported by the Foundation for Polish Science (FNP).

\section{References}

Adorno, Theodor (1973) Negative Dialectics. Ashton, E. B. (trans.). New York and London: Continuum.

Adorno, Theodor (2006) “Lyric Poetry and Society.” Mayo Brian (trans.). In: O’Connor, Brian (ed.) The Adorno Reader. London: Blackwell, 211-229.

Allen, Graham (2000) Intertextuality. London and New York: Routledge.

Anonymous (1983) "The Pain of Love." In: Woods, Frederick (ed.) The Oxford Book of English Traditional Verse. Oxford: Oxford University Press, 65.

Auden, W. H. (1991) Collected Poems. Mendelson, Edward (ed.) New York: Vintage.

Barthes, Roland (1977) Image - Music - Text. Heath, Stephen (trans.). London: Fontana.

Blake, William (1975) Poems and Prophecies. Plowman, Max (ed.) London: Everyman's Library.

Breuer, Heidi (2009) Crafting the Witch: Gendering Magic in Medieval and Early Modern England. New York: Routledge.

Easthope, Anthony (1991) "The Poetry of Ted Hughes: Some Reservations.” In: Moulin, Joanny (ed.) Lire Ted Hughes: New Selected Poems 1957-1994. Paris: Editions du Temps.

Eliot, T. S. (2002) Collected Poems 1909-1962. London: Faber and Faber.

Faas, Ekbert (1980) The Unaccommodated Universe. Black Sparrow: Santa Barbara.

Hughes, Ted (1994) Winter Pollen. Occasional Prose. Scammel, William (ed.) London: Faber and Faber.

Keats, John (1973) Poetical Works. Garrod, H. W. (ed.). Oxford: Oxford University Press.

MacNeice, Louis (1979) The Collected Poems of Louis MacNeice. London: Faber and Faber.

Marvell, Andrew (1984) The Complete Poems. DeF. Lord, George (ed.). London: David Campbell Publishers.

Mellors, Anthony (2005) Late Modernist Poetics: From Pound to Prynne. Manchester: Manchester University Press.

Mengham, Rod (2009) “'A Free Hand to Refuse Everything': Politics and Intricacy in the Work of J. H. Prynne.” In: Brinton, Ian (ed.) A Manner of Utterance. The Poetry of J. H. Prynne. Exeter: Shearsman Books, 69-82. 
Mengham, Rod and John Kinsella (eds) (2004) Vanishing Points: New Modernist Poems. Cambridge: Salt.

Nolan, Kevin (2003) "Capital Calves: Undertaking an Overview." Jacket 24. Australian Literary Management. Accessed on 13 Sep. 2016.

Plath, Sylvia (1965) Ariel. New York: Harper \& Row.

Pound, Ezra (1920) Hugh Selwyn Mauberley. New York: The Ovid Press.

Prynne, J. H. (1993) Stars, Tigers and the Shape of Words. London: Birkbeck College.

Prynne, J. H. (2001) The that Haue Powre to Hurt. A Specimen of a Commentary on Shake-speares Sonnets, 94. Cambridge: n.p., 2001.

Prynne, J. H. (2004) Poems. Tarset: Bloodaxe.

Prynne, J. H. (2007) Field Notes: "The Solitary Reaper" and Others. Cambridge: Cambridge Printers, 2007.

Reeve, N. H. and Richard Kerridge (1995) Nearly Too Much: The Poetry of J. H. Prynne. Liverpool: Liverpool University Press.

Shakespeare, William (1964) The Tempest. Longbaum, Robert (ed.). New York: Signet.

Shelley, Percy Bysshe (1951) Shelley: Selected Poetry, Prose and Letters. Glover, A. S. B. (ed.). London: The Nonesuch Press.

Wordsworth, William (1975) Selected Poems. Walford Davies, Damian (ed.). London: David Campbell Publishers.

Yeats, W. B. (2007) The Collected Works of W. B. Yeats: Volume IV, Early Essays. Finneran, Richard J. and George Bornstein (eds.). New York: Scribner.

Wit Pietrzak is Assistant Professor of English Literature in the Institute of English Studies, University of Łódź. He specialises in the English and Anglo-Irish poetry of the modernist period as well as contemporary English-language poetry. He is the author of Myth, Language and Tradition. A Study of Yeats, Stevens and Eliot in the Context of Heidegger's Search for Being (2011), Levity of Design. Man and Modernity in the Poetry of J. H. Prynne (2012), Życie po życiu (Life after death, 2012) and Ostrożnie, poezja! Szkice o współczesnej poezji anglojęzyczej (Careful, poetry! Sketches on the contemporary English-language poetry, 2015).

Address: dr hab. Wit Pietrzak, Institute of English Studies, University of Łódź, Pomorska 171/173, 90-236 Łódź, Poland [witpietrzak@wp.pl] 